\title{
FORCED LABOR SYSTEM DEVELOPMENT PECULIARITIES IN THE USSR DURING 1918-1920-IES
}

\author{
Yuriy D. Korobkov ${ }^{1}$, Svetlana S. Velikanova ${ }^{1}$, Maria S. Gallyamova ${ }^{1}$, Zinaida V. Arakcheeva ${ }^{1}$, \\ Natalia V. Kozhushkova ${ }^{1}$, Oksana P. Chernykh, ${ }^{2}$ \\ ${ }^{1}$ Nosov Magnitogorsk State Technical University, 38 Lenin Avenue, 455000, Magnitogorsk, \\ Chelyabinsk Region, Russia; \\ ${ }^{2}$ Moscow University of Finance and Law MFUA, 17/1 Serpukhov Val str., 115191, Moscow, Russia.
}

\begin{abstract}
Based on the involvement of a wide range of sources, the article considers the initial stage of the Soviet penitentiary system formation and development. This problem, closed during the Soviet era, enjoys an increased attention of experts after the USSR collapse, one of the consequences of which is the controversial nature of its various aspects many assessments. The article focuses on the most controversial problems of the penitentiary system contemporary historiography, such as the time of forced labor system origin and the repressive or educational nature of this system. In the course of the study, the author came to the conclusion that the starting point of its activity was 1919, when the forced labor camps were established. Another feature of this period was the continued struggle of various positions in the leadership of the country about the repressive or educational orientation of prisoner work until the end of the 20-ies. During the first post-revolutionary years, the prevailing view was the view concerning the educational value of forced labor and its payment at state rates. After the eradication of revolutionary romanticism era and under the influence of complex social-economic conditions of the country development the second point of view prevails by the end of the 1920-ies, which begins to be realized in practice in 1929 with the Gulag system development.
\end{abstract}

Keywords: forced labor, system development, peculiarity, USSR

\section{INTRODUCTION}

\section{Introduction to the problem}

The penitentiary system is one of the most important levers of state influence on society. With its help they solve the tasks of law maintaining, crime fighting and the prevention of violations.

In the political system of Soviet society, the penitentiary system occupied a special place and was an important element of the repressive mechanism, the means of population intimidation, and thus the study of its functioning was a closed topic and was beyond the limits of scientific knowledge. There has been a sharp increase of historian, lawyer, and publicist interest concerning this issue in modern Russia. This is largely related to the rethinking of Russian history, especially its Soviet period, the emergence of new Russian statehood, an optimal functioning of which requires a careful and an unbiased study of previous development experience.

\section{Problem relevance}


In addition to these factors, the intensification of research interest to this problem is conditioned by the declassification of a large body of documents, the study of which allows an objective assessment of the USSR penitentiary system development.

The choice of the forced labor system origin in the Soviet Union as an object of the study is also conditioned by the peculiarity of the modern historiographic situation, which consists in the presence of a large number of controversial points of view on various aspects of this problematics.

\section{Problem study}

The foundations of the Soviet penitentiary system historiography were laid in the 1920-ies through the works by S.V. Poznashev, E.G. Shirvindt, B.S. Utevsky, M.M. Isaev, in which the emphasis was on the educational character of prisoner work and affirmed that "the obligation of labor has nothing in common with the compulsion of labor."

Since the second half of the 30-ies the system of liberty deprivation places became closed to the public and to researchers. More opportunities appeared after Stalin's death to study the history of Soviet correctional labor institutions, but, in general, it remained under strict censorship control until the USSR collapse.

The feature of the modern historiographic situation is the controversial nature of various aspects of penitentiary system evaluation in the USSR. The most contentious among them are the issues about the time of forced labor system origin in the Soviet Union and its nature (forced or educational one).

Some researchers believe that the use of prisoners' labor was practiced long before the Bolsheviks came to power, since the second half of the seventies of the nineteenth century, when the commission, under the chairmanship of secret adviser K. Grot, was developing "common grounds for prison system reforming" (Borisov A.V., Detkov M.G., Kuzmin S.I., 1996). Some historians argue that August 9, 1918 can be considered as the date of the forced labor system origin, when Lenin wrote in the telegram to the Penza Regional Executive Committee: "It is necessary to organize a strong protection from the best reliable people, to conduct a merciless mass terror against kulaks, clergy and whiteguards; the doubtful has to be locked in a concentration camp outside the city" (Rozin E., 1996). Others consider April 15, 1919 as the starting point, when All-Russian Central Executive Committee issued the decree "On forced labor camps" (Yakovlev B., Burtsov A.) signed by M.I. Kalinin. There is the opinion that the first camp in this system is the Solovetsky Special Purpose Camp, founded on October 13, 1923 by the decision of the USSR People's Commissar Council (Kuzmin S.I., Dorofeev N.K.), which pushes away the creation of this system by 1923. Finally, the part of the researchers, connects the beginning of forced labor use within a nationwide scale with the origin of the Gulag system, which was initiated by the decree of the Central Executive Committee and the USSR Council of People's Commissars on November 6, 1929 concerning the imprisonment in forced labor camps, in the remote areas of the USSR (GULAG, 2000).

\section{Hypotheses}

The penitentiary system of any state is an integral part of its judicial power. Therefore, its evolution is closely related with the features of the state structure, the goals and the tasks of the authorities and reflects the change of state policy as a whole.

Taking into account this circumstance, we have the right to assume a complex and an ambiguous character of the power policy in relation to the role of the penitentiary system during the early stages of Soviet statehood and to be guided by the analysis of the entire range of approaches and opinions on this issue to reveal a repression element in the late 1920-ies within the absence of an original generic repressive nature of the Soviet penal system.

\section{METHODS}


Historical-comparative method, which makes it possible to consider the changes in the comparative context; historical-typological method, which allows to identify the main factors of state policy changes regarding the organization of forced labor of prisoners are the most valuable ones for the problems of this study. Its consideration in the broader context of Soviet Russia - the USSR transformation, predetermined the importance of the historical and systemic method taking into account the diversity of the corresponding changes.

\section{MAIN PART}

Considering labor as the most important means of "socially dangerous element adaptation to the conditions of a socialist way of life" the Bolsheviks did not see the need to abandon the system inherited from the old regime concerning the organizational forms of its use. The foundations of this policy were formulated by V.I. Lenin, who believed that the Soviet correctional labor policy should be based on the principles of law strict observance in the activity of corrective labor institutions, the possibility of correction for the persons who committed socially dangerous acts, the individualization of punishment execution, the combination of punishment execution with correctional labor influence on convicts, an all-round development of the Soviet corrective-labor system along the way "from prisons to educational institutions" (Garanzha S.A., 2012).

Focusing on these principles, the Bolsheviks attempted to use the work of those convicted directly in detention places initially. This desire was reflected in all normative acts of the power issued on this issue from 1917 to 1924.

The decree of the RSFSR PCJ "On Prison Work Teams" issued on January 24, 1918 stated that "1) Able-bodied prisoners develop work teams for the performance of works necessary for the state, which do not exaggerate a laborer's work. 2) Arrested ones (both the prisoners under investigation and convicted by courts) receive a fee for their work according to labor branches. 3) One-third of the mentioned goes to the general fund to improve the life of the arrested, and two-thirds registered for an arrested person and are given to him after release. 4) The tenth part of the earned money can be issued at an arrested person's request at the end of each working week" (Kokurin A.I., Petrov N.V., 2000).

The break of an old and the establishment of a new system of detention places was legally stated in the Provisional Instruction of the RSFSR People's Commissariat of Justice "On the Imprisonment as a Punishment and on the Procedure of Its Serving" issued on July 23, 1918. This instruction stated that "the prisoners capable of labor are necessarily recruited to physical labor", "the remuneration for those who serve sentences is made at the rates of trade unions from corresponding locations", "every prisoner has his own personal account and a book in which his earnings are registered as income and the costs of maintenance and the expenses incurred by the prisoners from their means are registered as expenses; in particular, the costs of correspondence, tobacco, and so on" (Collection, 1953).

Further, the Central Committee of the RSFSR PCJ singled out the circle of the most important tasks for detention places at that time in Circular No. 32 issued on August 7, 1918: "The renewal, the reconstruction and the creation of inter-prison workshops equipped with proper equipment, tools, materials and experienced instructors. The organization of work outside prisons, the development of prisoner remuneration principles on the basis of their maintenance costs reimbursement and the creation of a fund for the issuance of benefits upon release were described" (Markova E.V., 2001).

At the same time, the authorities set the task of using workshops not only for production work, but also for the professional training of convicts to work in a new, communist society. "Taking into account that a prisoner is placed into a modern situation after release. This situation requires skilled workers at least well trained to work with machine tools. The Punitive Section finds it unacceptable for prisoners to work on machines that have become history, and also considers it undesirable to train prisoners in handicrafts ... One of the main tasks of instructors and work managers is that the person 
who served the sentence could find the application of the acquired knowledge without undue difficulties" (Kokurin A.I., Petrov N.V., 2000).

The external work of prisoners was placed to the background in a circular. But due to a difficult economic situation in the country, the devastation that prevailed even in large cities and the deficit of free workers the work of prisoners was demanded outside the prison walls. The convicts were engaged in agricultural work at the nearest settlements from prisons, the transportation of hay and the delivery of water, they worked at the mills, were engaged in the repair of houses, the harvesting of firewood, peat, coal unloading, the cleaning of premises and streets, the removal of garbage and snow, that is, they performed any rough work.

The most common internal work was the labor in tailor, shoemaker and other workshops of the camps, at the forge and bakery. The workshops for the production of uniforms, boots and work boots for the Red Army were created on the territory of some camps (Rylov V., 2011).

In a generalized form, the official point of view concerning the place of forced labor camps in the system of punitive institutions was set forth in Resolution V of All-Russian Congress by the heads of Executive Committee departments from Local Soviet authorities. It states that "Punitive measures in the present transitional period are a serious tool in the hands of the state to ensure a healthy life of the country. In order to protect society from criminal encroachments and to influence the correction of a guilty one, the punishment by the deprivation of liberty must have the features different from those practiced under the bourgeois system in the conditions of the proletariat dictatorship existence. Instead of hard labor and other types of imprisonment, which previously pursued the task of isolation, the forced labor in its true meaning of the production factor with a deep educational content is being brought to the forefront now. Accordingly, on the one hand, forced labor with the complete isolation of a guilty, on the other hand, and forced labor without the deprivation of liberty, on the other hand, and the creation of a forced labor camp by revolution as an intermediate measure" (Collection, 1953).

A little later a new expanded decree "On forced labor camps" was published on May 17, 1919, signed by the chairman of All-Russian Central Executive Committee V. Avanesov. In accordance with it and the decree of the Central Executive Committee issued on March 21, 1919, they started to establish concentration camps subordinated to the AREC and forced labor camps subordinated to the NKVD. When they were organized, the physical labor of prisoners was pointed out as obligatory and their labor was paid at the rates of trade union branches. The maintenance of a camp and the administration was to be paid off by the work of all prisoners.

All this allows us to consider 1919 as the time of forced labor system approval in detention places. At the same time, and in the early 20 -ies there was the predominant orientation to the educational, rather than repressive impact of labor on convicts.

In particular, a lot of attention was paid to the re-education of prisoners in the departmental normative acts of AREC. The order "On the punitive policy of AREC authorities" issued on January 8, 1921 was aimed to attract the public to the re-education of offenders. The departmental documents were fixed by the Decree of People's Commissar Council "On the Imprisonment and on the Procedure for the Early Release of Prisoners" issued on March 21, 1921, which set the task to provide them with the opportunity of working life correction and adaptation, and, the entire system had to implement humane approach to a criminal identity in general, since according to the opinion of the Bolshevik leaders "professional criminality should disappear in the conditions of a new social system" (Zubkov A.I., 1997).

When the network of camps was created, the work of prisoners began to be used to develop forest tracts in Karelia, Siberia, the Pechora area and the minerals in Ukhta, Pechora, Vaigach Island, and Siberian mines. A gradual expansion of the camp network begins. Prisoners were brought to the taiga, tundra, and islands in the uninhabited areas, sometimes hundreds of kilometers from administrative 
centers. Their first task was the construction of premises for administration and protection, huts, dugouts, barracks for themselves, the fencing of camps with wire, and then an exhausting physical work in the woods, galleries, on floating, which for the vast majority of prisoners ended by death (Yakovlev B., Burtsov A., 1955).

132 camps were established in the country, 26 of them in Siberia and in national areas during the period of 1919 - 1921. There were 59636 prisoners in 84 active camps on Nov. 1, 1920, 67\% of convicts were employed, which was a very high indicator for world penitentiary practice (Morukov M., 2006). By the end of 1921, the number of prisoners was about 16,000, since the release of war prisoners took place in connection with the end of the Civil War.

From January 1, 1922, all forced labor camps were transferred to self-sufficiency and self-financing. In order to coordinate the production and economic activities, the Central Economic Directorate of production enterprises was set up in the forced labor camps - "Princust", its Charter was approved on March 4, 1922. According to the report of CDIP NKVD RSFSR the works on existing production facility reinforcement and new workshop creation that worked on the basis of self-financing took place since October 1923 until October 1924. The result of these measures is the increase of domestic work employment from $16.9 \%$ to $22.9 \%$, and 1291 handicraft workshops were built at corrective labor institutions by the end of 1924, 113 of which were not inferior to factories in terms of production level. The work on such factories made it possible to receive a profession for prisoners and improve their qualifications. In spite of the fact that they issued the circulars of CDIP NKVD RSFSR "On vocational training of prisoners" and "General provision for vocational training in detention places", the vocational training was not widely spread among prisoners in 1920-ies. This was conditioned by the lack of material and human resources that could train professionals (Zubkov A.I., 1997).

Unlike CDIP, NKVD considered the external work as the main type of works for prisoners. This position can be seen in the circular letter of CITO No. 15 issued on March 8, 1922 and addressed to the provincial and regional departments of justice, which stated the following: "Since it is not possible to organize workshops in the amount sufficient to engage all prisoners into the work, then the correctional labor subdivisions need to pay their attention to the development of external works and in cases of insufficient convoy or staff wardens, to guard the prisoners at work, to hire a required amount of supervision additionally due to $50 \%$ of the deductions from these works ... "(Khlevnyuk O.V., 2004).

However, in the conditions of mass unemployment, local party and business leaders did not recommend compete in order placement for enterprises where free citizens worked. Even by April of 1928, 1576 thousand people were registered on labor exchanges. In this regard, prisoners were left without work more and more often. Thus, for example, in 1923 and 1924, the occupation with external work made $33.9 \%$ and $23.2 \%$, respectively (Zhigalev A.V., 2010). This situation was also due to the fact that because of the transition of camps to self-repayment, the rent of large state farms and factory enterprises becomes impossible due to a shortage of labor in the camps because of work seasonality and the instability of prisoner composition. Thus, the Main Directorate was forced to raise the issue of prisoner redistribution between individual camps, taking into account the necessary production (M.G. Detkov, 1992).

At the end of November and the beginning of December 1924, the IInd Congress of Penitentiary Workers was held, during which they raised the issue of prisoner bringing to domestic works. At the same time, the congress participants identified a number of problems that significantly limited, and more often excluded the possibility of prisoner labor use: the lack of funds (for example, by 1925, 32 RSFSR prisons were financed from the state budget, the rest were given to local budgets); a lot of short-term prisoners; the lack of supervising staff and convoy; the dependence of earnings on camp location; a large number of peasants among prisoners who were engaged in unskilled labor (Morukov M., 2006). 
The representatives of the congress saw the way out of this situation in the creation of work units at the places of liberty deprivation. This was expressed by the provision of production premises through prison management and the workforce to individual entrepreneurs and organizations on the terms of some profit receiving to improve the conditions of prisoner detention within a leasehold basis. A work unit chose the direction and the mode of economic activity itself. Due to the fact that the execution of such works required a highly skilled workforce, the production equipment for the production of a wide range of products, which was not available at the places of detention, this method of prisoner employment was not popular during this period of time.

Concerning the involvement of those convicted to external work, the representatives of the congress said that such work is possible if two conditions are fulfilled: "firstly, the place of detention place location should have no possibility of internal production organization; secondly, the work of convicts should not be competitive to free labor in any case" (Kokurin A.I., Petrov I.V., 2000). Given these circumstances, the prisoner work began to be used in the area where high qualifications were not required: agricultural colonies, subsidiary farms, logging, road construction, furniture production and fishing. In general, the possibility of unskilled labor use in external jobs during 1920-ies was limited by the unemployment in the Center, in the Volga region and in the Urals.

The attempts to create subsidiary farms on the basis of All-Russian Central Executive Committee and the Council of RSFSR People's Commissars decree issued on May 10, 1926 at the places of detention for the production of commercial, industrial or economic operations and the organization of forced labor without detention, i.e. at the place of their work on the basis of All-Russian Central Executive Committee and RSFSR Council of People's Commissars decree issued on September 6, 1926, were also blocked by the prevailing economic situation in the country and proved to be failed.

Therefore, the All-Russian Central Executive Committee and the Council of People's Commissars of the RSFSR in their resolution "On Punitive Politics and the Condition of Prisons" issued on March 26, 1928, proposed to PCJ and NKVD of RSFSR "to draft a forced labour law for an actual use of forced labor as the means of criminal repression on the basis of the following terms: a) free of charge, b) economic profitability, c) in such an organization that they represent a real measure of repression as compared to the public works organized for the unemployed by PCL.

Payment can be tolerated only in respect of persons serving forced labor at a duty station, or each time by a special court ruling for the persons who do not have any means of subsistence at all; However, the amount of payment for these cases should not exceed the state minimum of the given area" (Collection, 1953).

The Main Directorate of Prisons (MDP) of NKVD RSFSR stated that instead of building new institutions, the emphasis should be placed on labor colony occupancy increase at the expense of inactive or unprofitable agricultural, handicraft and factory enterprises.

The introduction of free of charge and low payment in those historical conditions was the decisive factor for the development of corrective labor, as, on the one hand, it increased their repressiveness and educational impact to the level necessary for criminal punishment, and on the other hand, simplified the issue of convict work use greatly, since there were a lot of free public works (the construction of buildings, the repair of roads, bridges, etc.) in cities and villages.

In October 1928 the problem of prisoner employment was raised again at the First All-Russian Meeting of Penitentiary Workers.

The reports and speeches said that about $40 \%$ of prisoners are employed at various works in RSFSR, the main kind of work is the works in the workshops, that the turnover of enterprises in the places of liberty deprivation amounted to about 30 million rubles in 1927. But the speakers noted that these results are inadequate ones (Morukov M., 2006). 
It was also said that "year by year MDP appeals to local authorities of detention places with proposals to remove the obstacles that do not allow a sufficient development of work at detention places. And for a long time it gets the same answers from the field in the most part: "There are no production premises, the fluidity of labor force takes place, is has no qualified core, there is no working capital, the production equipment is insignificant, and there is no means to strengthen or improve it, it is impossible get raw materials, there is no sale." (Khlevnyuk O.I., 2004). The result of the congress was the development of principles for the organization of labor and the employment of prisoners for the future: 1) If a prisoner is healthy, he must be involved in socially necessary, productive work, since he must repay his costs with his labor, at least his immediate maintenance. 2) Необходимо все места заключения перевести на самоокупаемость. 2) It is necessary to transfer all detention places to selfsufficiency. The workers of the same part of detention places were recognized as state enterprises, the cells of the state sector of industry. 3) The work of prisoners is used not only from the standpoint of economic efficiency, but also as a parenting element. 4) The enterprises of detention places are an independent entity, headed by a colony head, they have their own statutes and are independent of trusts (M.G. Detkov, 1992).

In order to ensure the principle of forced labor camp self-sufficiency, the meeting decided to "Bring the maximum of prisoners from detention places in cities to agricultural colonies and organize mass external works for forestry and mining in remote areas" (Khlevnyuk O.V., 2004). The implementation of this decision began on July 11, 1929 at the highest level, when the decree "On the use of criminal prisoner labor" was adopted, which laid the legal basis for a new stage in the history of prisoners' labor use, which is called the GULAG of NKVD MIA USSR.

\section{CONCLUSIONS}

Thus, from the beginning of forced labor system development in 1919 and throughout the 1920-ies, the Soviet state makes the attempts to expand it both to solve the economic problems faced by the country, and for labor education and re-education of prisoners and their return to an honest life in a new socialist society.

Although the leading trend in this process was the repressive component that ultimately led to the creation of Gulag "archipelago", one can not say about an original repressive nature of the Soviet penitentiary system as many liberal historians believe.

It should be emphasized that many attempts were made to use the mass labor of prisoners in the most rational way during this period, since labor was not only an element of re-education for them, but also allowed to solve the economic problems faced by the state at least material costs. It is sufficient to say that at the beginning of this period the use of prisoners in external and internal works was not repressive one, and their work was paid. Then, as the political course was adjusted in connection with the strengthening of Stalin's position, the work of prisoners began to be paid only in rare exceptional cases because of the Party economic strategy change, and the entire system took on a pronouncedly repressive character.

\section{Conflict of interest}

The authors confirm that the presented data do not contain a conflict of interest.

\section{REFERENCES}

Borisov A.V., Detkov M.G., Kuzmin S.I. (1996). The bodies and the troops of the Ministry of Internal Affairs of Russia: a brief historical essay. M.: United editorial board of the Ministry of Internal Affairs of Russia. - 464 p. [in Russian].

Garandzha S.A. (2012). The correctional labor policy of the Soviet state (on the example of RSFSR general detention places) in 1917-1934. M. - 228 p. 
GULAG: General Directorate of the camps. 1918-1960. (2000) / Ed. in charge A.N. Yakovlev; comp. by A.I. Kokurin, N.V. Petrov. - M.: MFD. - 888 p. [in Russian].

Detkov M.G. (1992). The content of the penitentiary policy of Russian state and its implementation in the system of criminal punishment execution in the form of imprisonment during the period of 19171930. M.: Publishing house of RIPK of IDA employees. - 192 p. [in Russian].

Detkov M.G. (1999). Prisons, camps and colonies of Russia. M.: "Verdict-IM". - 448 p. [in Russian]. Zhigalev A.V. (2010). Administrative and legal features of production activity organization at the places of freedom deprivation or restriction in Russia during 20-ies - early 30-ies of the XXth century. // Bulletin of the Vladimir Law Institute. - Vladimir: The publishing house of VJI FSPE of Russia № 4 (17). pp. 182-190. [in Russian].

Zubkov A.I. (1997). Criminal-executive law of Russia: the textbook for law schools and faculties. M.: INFRA M-NORM. - 614 p. [in Russian].

Isaev M.M. (1926). The foundations of penitentiary policy. Moscow: Gosizdat. - 196 p. Access mode: http://www.lawlibrary.ru/izdanie24340.html.

Kokurin A.I., Petrov N.V. (2000). GULAG (General Directorate of Camps) during 1917-1960: the collection of reports. Moscow: International Foundation "Democracy". - 700 p. [in Russian].

Kuzmin S.I., Dorofeev N.K. Legal support of corrective labor institution operation during the Great Patriotic War. Access mode: http://www.lawmix.ru/comm/1139. [in Russian].

Markova E.V., Volkov A.N., Rodny A.N., Yasny V.K. (2001). Gulag secrets of the North development / Ed. in charge Pashkovsky I.S. Moscow: Stroyizdat. - 326 p. [in Russian].

Morukov M. (2006). The truth of the gulag from the first circle. M.: Algorithm. - 192 p. [in Russian].

13. Poznyshev S.V. (1923). Fundamentals of penitentiary science. M.: Legal publishing house of People's Commissariat of Justice - 371 p.

Rozin E. (1996). Lenin's mythology of the state. M.: Lawyer. - 320 p. [in Russian].

Rylov V. (2011). Forced labor and concentration camps in Voronezh during 1919-1922. Access mode: http://legitimist.ru/sight/history/2011/aprel/prinuditelnyij-trud-i-konczentrac.html. [in Russian].

The collection of documents on the history of criminal of the USSR and RSFSR legislation: 1917-1952 (1953). / Ed. by I.T. Golyakova. - Moscow: State publishing house of jud. lit. - 463 p. [in Russian].

Utevsky B.S., Shirvindt E.G. (1957). Soviet correctional labor law. M., Gosyurizdat - 244 p. Access mode: http://www.lawlibrary.com/izdanie5239.html. [in Russian].

Khlevnyuk O.V. (2004). The history of Stalin's Gulag. The end of the 1920-ies - the first half of the 1950-ies: the collection of documents: 7 volumes. V. 3. The Gulag economy. Moscow: ROSSPEN. $624 \mathrm{p}$.

Yakovlev B., Burtsov A. (1955). Concentration camps of the USSR (excerpts): Institute for the Study of the USSR history and culture. Studies and materials, series 1, 23-rd edition, Munich. Access mode: http://lib.ru/POLITOLOG/lageri.txt. [in Russian]. 